\title{
知識の転移と選別機能を備えた強化学習手法の 複数タスク下における性能検証*
}

小谷 直樹 †

\author{
A Verification of Reinforcement Learning with Knowledge \\ Transfer and Knowledge Selection in Multitask Learning*
}

Naoki KOTANi ${ }^{\dagger}$

\section{1.はじめに}

環境との相互作用を通して進化する強化学習 [1]などを 用いたエージェントに関する研究がなされている。 なか でも，さまざまなタスクを学習する過程で獲得した知識 を蓄え，それらを異なるタスクを解く際に転移し，エー ジェントの学習効率を高める転移学習 [2]がある.

これまでに, 複数タスクを扱う強化学習問題の効率化 を目的として, 知識の転移と選別機能を備えた強化学習 手法を提案してきた $[3]$. 複数夕スクを扱う強化学習問題 では，学習するタスクが増えるにつれてエージェントの 知識量も増える。このとき, 状態空間を適応的に構築し ながら学習する場合，タスク達成に不要な知識が大量に 生成される問題がある。そここで，状態価值の低い知識を 不要な知識として削除すること（知識の選別）によって 知識量を削減し，学習時間を抑制する手法を提案した [4].

その一方で，状態価值に基づく知識の選別が，たとえ ば過去に学習を終えたタスクを再度実行する場合，エー ジェントのタスク達成に与える影響については評価でき ていなかった，本研究の目的である学習の効率化におい て，仮に知識の選別による悪影響によって一度獲得した タスク達成に必要な知識を蒧失するとすれば，再度同一 タスクを学習する必要がありむだである。本研究では， 知識の選別による獲得知識への悪影響の有無についてシ ミュレーションによって検証した。

また本研究では, 転移学習に打いて, 学習する夕スク の順序が，エージェントのタスク達成に及ぼす影響につ いても検証した．夕スク間に何らかの関連性や類似性が あり，かつ，設計者が事前にタスクの難易度を想定しう る場合, 同じタスク群を学習するとしても, エージェン トが解決しやすいタスクからむずかしいタスクへと学習 することによって，転移学習の効果が，より発揮される

* 原稿受付 2015 年 4 月 30 日

$\dagger$ 大阪工業大学 情報科学部 Facility of Computer Science and Technology, Osaka Institute of Technology; 1-79-1 Kitayama, Hirakata City, Osaka 573-0196 , JAPAN Key Words: reinforcement learning, transfer learning, multitask learning, knowledge, value.

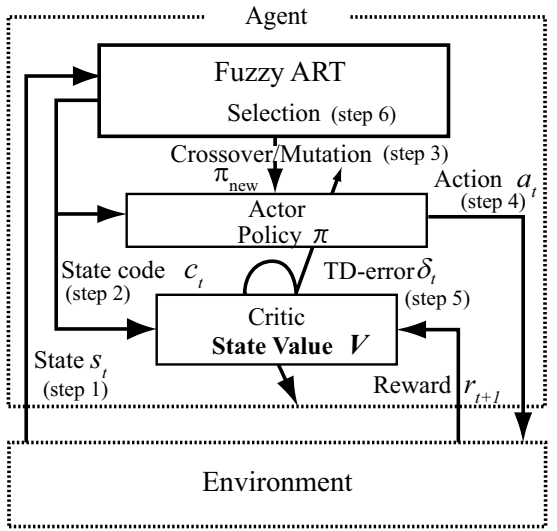

Fig. 1 Reinforcement learning method with knowledge transfer and knowledge selection based on the concept of genetic algorithm

と期待される。これを確認できれば, 一度の学習で解決 できない複雑な夕スクを，それに関連した解決可能なや さしいタスクを解決するなかで得た知識を転移するこ とによって, 最終的に複雑なタスクを解決できるように エージェントの知識が発展していくと期待される.

本研究では, これら複数タスク下に打ける強化学習問 題についてシミュレーションによる検証を行った。

\section{2. 学習アルゴリズム}

アルゴリズム [4] の概要を述べる. 本研究で用いる学 習アルゴリズムのモデルを Fig. 1 に示す，学習アルゴリ ズムは, Actor-Critic[1] と状態空間を適応的に構築する ART から構成されている。.また, 複数のタスクを効率 的に学習するために, 知識の転移と選別を行う。ここで, 知識とは, 状態と行動（政策）を最小構成単位とする情 報を指すものとする。

知識の転移は, エージェントが未知の状態に遭遇した とARTによって判別されたとき, 過去の学習によって 獲得した知識のなかから, それと類似したいくつかの状 態に対応した政策を基にして, 未知状態の政策の初期值 を導出する (Fig. 1中 step 3)。これによって, エージェ ントは, 未知の状態であってもタスクを達成する確率が 
高いと思われる行動を選択しやすくなる。

つぎに，知識の選別は，記憶量を抑制し学習を効率化 する。複数タスクを扱う強化学習では，一般的に学習す るタスクが増えるほど，その知識量も膨大になる。この とき，本アルゴリズムのように状態空間を適応的に構築 する場合，学習の過程において，結果的にタスク達成に 繋がらない不要な知識も多数含まれる。これらの知識 は，夕スク達成に繋がらない情報であるため，知識転移 の際に参照するとエージェントの学習効率を低下させる 恐れがある。終端状態でのみ報酬が与えられるような工 ピソード的では，夕スク達成に必要な最小の状態価值を 計算可能であり，その最小価值よりも小さな価值をもつ 状態 (知識) は, 夕スク達成に必要のないものと見なす ことができる。すなわち，知識の選別基準として状態価 值 $V$ を用い，そのしきい值 $V_{t h}$ は，報酬 $r ，$ 割引率 $\gamma, 1$ エピソードにおける最大ステップ数 $T$ を用いて

$$
V_{t h}=r \gamma^{T}
$$

となる。このしきい值より小さな価值を持つ知識は，不 要な知識として消去する（Fig. 1 中 step 6）。

\section{3. シミュレーションによる検証と結果}

\section{1 問題設定}

シミュレーションの内容と各種設定は [4] と同様であ るため, 概要のみ説明する。シミュレーションに用いる 6 関節圥長ロボットのシミュレーションのモデルを Fig. 2 に示す。モデル内の長さの単位は，すべて任意とする。 多関節ロボットは，図中に示すように，Y 軸上に沿って 中間関節で折り返された初期状態から学習を始めるもの とする。このタスクでは，エージェントが，Fig. 2 内の 中空円で示した直径 100 の円内に, 図中の $\square$ で示した多 関節ロボットのエンドエフェクタの先端を到達させる軌 道を学習することを目的とする。中実円で示した直径 50 の円は，障害物である。この強化学習問題では，障害物 の配置座標の違いによって，異なる夕スクを表現できる. Table 1 に, タスクごとの障害物の位置を示す。ここで は，10個のタスクを学習する。

学習条件として，エージェントは，学習に必要な状態 をすべて観測可能であり， 1 試行につき最大 $T=50$ ス テップ動作できるものとする。終端状態は，エージェン トが 50 ステップ動作するか，多関節ロボットのエンドエ フェクタの先端が目標領域内に到達した場合とする。報 酬は，目標領域内に到達した場合のみ $r=+10$ が与えら れる. $\gamma=0.9$, 知識の選別基準 $\left(V_{t h}\right)$ を $10 \cdot 0.9^{50}$ とし, これよりも小さな価值を持った知識を消去する。

\section{2 知識の選別がタスク達成に及ぼす影響}

ここでは，知識の選別が獲得した知識に及ぼす影響に ついて，エージェントを過去に学習したタスクに再度遭 遇（再実行）させることによって検証した。シミュレー ションでは，エージェントがタスク 1 から 10 を順に 1 万

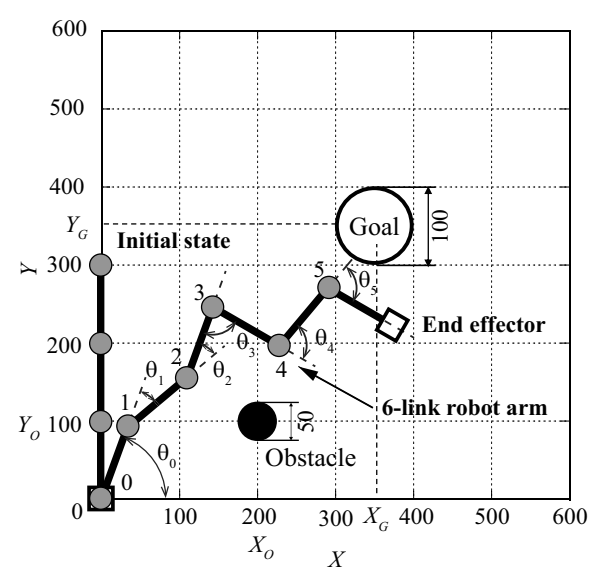

Fig. 2 Reaching task in 6-link robot arm

Table 1 The positions of obstacle in each task

\begin{tabular}{c|cc}
\hline \hline Task No. & $X_{O}$ & $Y_{O}$ \\
\hline Task 1 & 100 & 100 \\
\hline Task 2 & 100 & 200 \\
\hline Task 3 & 200 & 100 \\
\hline Task 4 & 200 & 200 \\
\hline Task 5 & 100 & 150 \\
\hline Task 6 & 150 & 100 \\
\hline Task 7 & 150 & 150 \\
\hline Task 8 & 150 & 200 \\
\hline Task 9 & 200 & 150 \\
\hline Task 10 & 200 & 250 \\
\hline \hline
\end{tabular}

試行ずつ学習した後，一つの夕スクにつき 1000 試行ず つ再実行する。 また, 再実行時の夕スクの順序は, 無作 為に決定した $3 \rightarrow 10 \rightarrow 8 \rightarrow 7 \rightarrow 6 \rightarrow 2 \rightarrow 5 \rightarrow 9 \rightarrow 1 \rightarrow 4$ とする。知識の転移は，一度目の夕スク 1 の学習が終了 した後から行い，知識の選別は一つの夕スクが終了する ごと（1万試行ごと）に行った

Fig. 3 に最初の学習である 10 万試行までの夕スク達 成率の推移 (a) と再実行したとき（10万試行後）の夕ス ク達成率の推移 $(\mathrm{b})$ を示す。 タスク達成率は，ある 100 試行区間における成功回数であり，Fig. 3 は，異なる乱 数セットで与えられる 10 回のシミュレーションにおける 夕スク達成率の平均である。図中の丸囲みの数字は夕久 ク番号を表している。

Fig. 3(a)の結果から, タスク 3，4，6，7，8，9，10 は，それぞれ $90 \%$ 以上のタスク達成率を示しており，十 分に学習できていることが確認された。 ただし，タスク 7 は 10 回の学習セットのうちの一つで局所行動に陥った 場合があった。一方，夕スク $1 ， 2 ， 5$ におけるそれぞれの 学習終了時点の夕スク達成率は， $30.3 \% ， 46.8 \%, 56.4 \%$ であり，他と比べてゴール到達までの軌道を十分に獲得 できたといえる結果ではなかった。この原因は，夕スク 1，2，5における障害物の位置は $X=100$ 上にあり， ロ ボットアームの初期姿勢との位置関係が近く，ロボット アームは障害物と接触しやすくなり，障害物を回避する 行動を獲得することがむずかしくなるためである. 


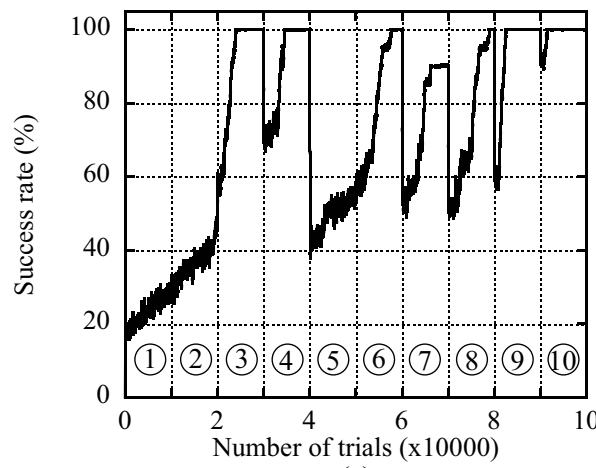

(a)

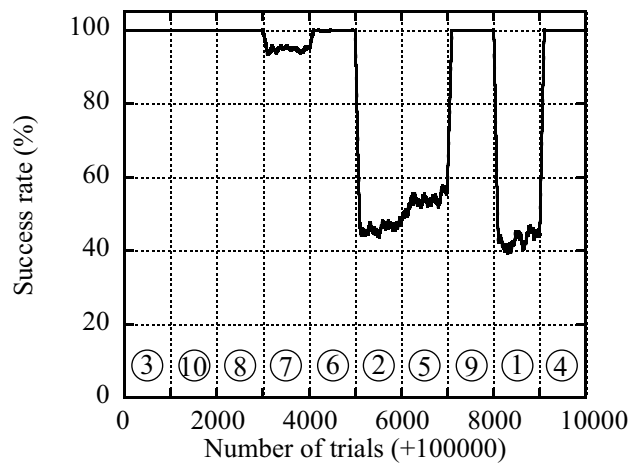

(b)

Fig. 3 Success rate; (a) 1st time learning, (b) 2nd time learning (the order of task is different from (a))

つぎにFig. 3(b) の結果を見ると，一度目の学習で十 分に学習されたタスク $3 ， 4 ， 6 ， 7 ， 8 ， 9 ， 10$ は，再度同 じタスクに遭遇してもタスク達成率は一度目の学習と同 様に $90 \%$ 以上で推移しており，十分にタスクを達成でき ていることを確認した。一方，一度目のタスクで十分な 達成率を得られなかったタスク $1 ， 2 ， 5$ において，再実 行終了時点での夕スク達成率は $44.2 \%, 47.5 \%, 56.8 \%$ であるが，タスク達成率の低下は見られなかった。

以上のことから, 知識の選別は, タスク達成に不要な 知識のみを消去しているため, 夕スク達成に必要な知識 を失っては扔らず，再実行しても過去に学習したときと 同程度のタスク達成能力を保持していることを確認した。

\section{3 タスクの順序がエージェントの学習に及ほ す影響}

3.2 のシミュレーション結果から，タスク $1 ， 2 ， 5$ は, 十分なタスク達成率を得られなかった。このことから， エージェントにとって，タスク $1 ， 2 ， 5$ は他のタスクに 比べて達成がむずかしい夕スクであると考えられる。そ こで，達成がむずかしいと思われる夕スクを後に回し， タスク達成率の高い比較的やさしいと思われるタスク から順に学習することによって, 学習結果に違いが現 れるか検証した。ここでは，学習するタスクの順序を $3 \rightarrow 4 \rightarrow 6 \rightarrow 7 \rightarrow 8 \rightarrow 9 \rightarrow 10 \rightarrow 1 \rightarrow 2 \rightarrow 5$ と変更し, 10 回の異なる乱数セットでシミュレーションを行った。 そ の平均の結果を Fig. 4 に示す。

本シミュレーションでは, タスク $3,4,6,7,8,9$,

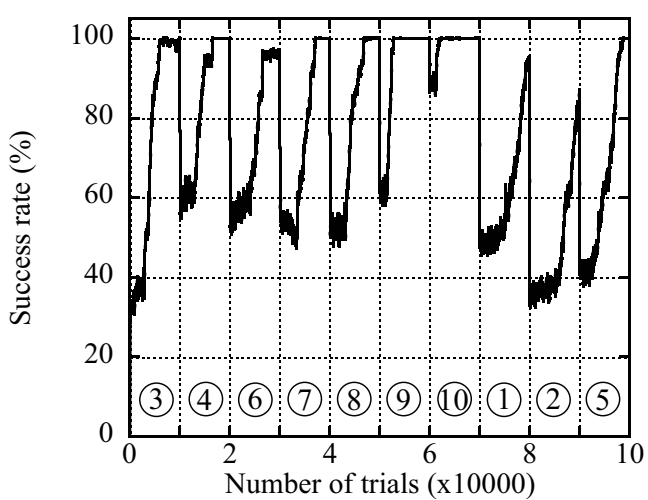

Fig. 4 Success rate in order of increasing task difficulty 10 は、いずれも $100 \%$ 近い高いタスク達成率を示して いる.タスク 7 においては, 3.2 の場合とは異なり，局 所行動に陥る学習セットはなかった。 そして, タスク 1 , 2, 5 の終了直前 100 試行の夕スク達成率は，それぞれ 95.5\%，86.8\%，100\%であり，3.2で示したタスク達成 率 $30.3 \% ， 46.8 \% ， 56.4 \%$ を大きく上回るものとなった。

これより，本シミュレーションのように，設計者が夕 スクの難易度を予測できる場合，達成が容易な夕スクか ら順にエージェントに学習させることによって，タスク を効率的に学習できることを示した

\section{4. おわりに}

本研究では, 複数夕スクを扱う強化学習問題の効率化 を目的として，これまでに提案してきた知識の転移と選 別機能を備えた強化学習手法について, 知識の選別を 行った後に同じ夕スクを再実行したときの夕スク達成能 力と，学習するタスクの順序がタスク達成に及ぼす影響 の二点について検証を行った.

その結果，タスク達成に不要な知識を削除しても，一 度学習が完了したタスクの達成には悪影響を及ぼしてい ないことを確認した。また，エージェントは，達成がや さしいタスクからむずかしいタスクへと順に学習するこ とによって, 複雑なタスクに対応できるだけの高度な知 識を段階的に獲得できることを示した。

\section{参 考文 献}

[1] R. S. Sutton and A. G. Barto（著）, 三上, 皆川（共 訳）：強化学習, 森北出版 (2000)

[2] M. E. Taylor and P. Stone: Transfer learning for reinforcement learning domains: A survey; Journal of Machine Learning Research, Vol. 10, No. 1, pp. 16331685 (2009)

[3] 小谷, 谷口：遺伝的アルゴリズムを適用した Fuzzy ART による2リンクロボットアームの行動獲得の効率化; シス テム制御情報学会論文誌，Vol. 23, No. 7, pp. 157-163 (2010)

[4] 小谷：転移学習における価值に基づく知識の選別；シス テム制御情報学会論文誌, Vol. 28 , No. 6, pp. 275-283 (2015) 